\title{
Epidemiology of neonatal tetanus in the Rivers State of Nigeria: a community based study
}

\author{
P N C Abuwa, E A D Alikor, P V Gbaraba, K S Mung, R S Oruamabo
}

Globally, over 1000000 new cases of neonatal tetanus occur annually. About $75 \%$ of these babies die, most of them in countries of the third world. ${ }^{1}$ Data from Nigeria are largely hospital based, but case fatality rates currently are approximately $50 \% .^{23}$ However, in one community based study, the mortality rate was 11.9 per 1000 live births. ${ }^{4}$ In the University of Port Harcourt Teaching Hospital, Nigeria, over 50 new cases are still seen annually, despite the fact that a comprehensive immunisation schedule was launched in the country in 1984. This study aimed to estimate the true mortality from neonatal tetanus in the community and to assess the tetanus toxoid vaccine coverage status of parturient women.

\section{Method}

This was a retrospective, cross sectional, community based survey which took place between 1 January 1991 and 31 December 1992. The subjects consisted of parturient women. Sample size estimation, sampling, and interviews were done using standard methodology. Definitions of neonatal tetanus and tetanus toxoid coverage of pregnant women were based on WHO criteria. ${ }^{5}$ The study was approved by the ethics committee of the hospital and the $\chi^{2}$ test was used for statistical analysis.

\section{Results}

Altogether 2618 women were surveyed and there were 2706 deliveries - 1450 boys and 1256 girls (a male:female ratio of 1.15:1). There were 49 neonatal deaths attributable to tetanus ( 36 boys and 13 girls), a mortality of 18.1 per 1000 live births. Over $70 \%$ of the cases of tetanus occurred in babies born in the homes of traditional birth attendants and private maternity units, but approximately $24 \%$ per cent were among babies born in government maternity units and health centres. In table 1 , mortality from neonatal tetanus is shown in relation to the places of delivery of the babies and vaccine coverage of their mothers. Complete vaccine coverage was greatest among mothers who delivered in government hospitals compared with those who delivered elsewhere $\left(\chi^{2}=309.83 ; \mathrm{df}=6, \mathrm{p}<0001\right)$.

\section{Discussion}

A mortality rate from neonatal tetanus of 18 per 1000 live births is definitely very high, even by the standards in the African subregion. ${ }^{1}$ An earlier community based study in Nigeria gave a mortality rate of 11.9 per 1000 live births. ${ }^{4}$ An important finding in this survey is that the occurrence of neonatal tetanus is determined more by a combination of factors rather than their acting singly. Neonatal tetanus was not recorded in any baby born in government hospitals. The vaccine coverage rate among mothers who delivered in government hospitals was higher than that in mothers who delivered elsewhere. It is probable that staff helping with deliveries in government hospitals are more likely to observe the rules of aseptic techniques and antiseptics, particularly in relation to care of the cord. Furthermore, the mothers who elected to deliver in these hospitals are more likely to have received ante natal care during the pregnancy, including tetanus vaccinations. There is little difference in the quality of care given in private maternity units and the homes of TBAs, with the exception that the former are more often located in urban centres than the latter.

In addition to instituting measures aimed at increasing vaccine coverage in women of child bearing age and ensuring a regular supply of potent vaccines, retraining of TBAs should begin, and should include techniques of administering tetanus toxoid vaccine. Practices at government clinics and maternity units should be monitored regularly to ensure adherence to simple aseptic techniques at childbirth.

1 Stanfield JP, Galazka A. Neonatal tetanus in the world today. Bull WHO 1984;62:647-89.

2 Oruamabo RS, Mbuagbaw LT. Neonatal tetanus in Port Harcourt. Nigerian fournal of Paediatrics 1986;13:115-20. 3 Antia-Obong OE, Ikpatt NW. Neonatal tetanus in Calabar: a four-year retrospective study. Nigerian fournal of Paediatrics 1991:18:94-99.

4 Babaniyi O, Parakoyi B. Cluster survey for poliomyelitis and neonatal tetanus in Ilorin, Nigeria. Int $\mathcal{f}$ Epidemiol 1991; 20:515-20.

5 World Health Organization. Guidelines for investigating suspected cases of neonatal tetanus. WHO/EPI/TRAM/93.3. Geneva: WHO, 1993; 9.

Table 1 Mortality from neonatal tetanus (NNT) in relation to place of delivery and tetanus toxoid vaccine coverage of the parturient women

\begin{tabular}{|c|c|c|c|c|c|c|c|c|c|c|}
\hline \multirow[b]{3}{*}{$\begin{array}{l}\text { Vaccine coverage } \\
\text { of parturient } \\
\text { women }\end{array}$} & \multicolumn{10}{|c|}{ Place of delivery of the babies } \\
\hline & \multicolumn{3}{|c|}{$\begin{array}{l}\text { Homes of } T B A s \\
(n=775)\end{array}$} & \multicolumn{3}{|c|}{$\begin{array}{l}\text { Government maternity units and health } \\
\text { centres }(n=785)\end{array}$} & \multicolumn{3}{|c|}{$\begin{array}{l}\text { Private maternity units } \\
(n=818)\end{array}$} & \multirow{2}{*}{$\begin{array}{l}\text { Government } \\
\text { hospitals }(n=144) \\
\text { No }(\%) \\
\text { of } \\
\text { deliveries }\end{array}$} \\
\hline & $\begin{array}{l}\text { No }(\%) \\
\text { of } \\
\text { babies }\end{array}$ & $\begin{array}{l}\text { No (\%) } \\
\text { NNT } \\
\text { deaths }\end{array}$ & $\begin{array}{l}\text { Mortality/ } \\
1000 \\
\text { deliveries }\end{array}$ & $\begin{array}{l}\text { No (\%) } \\
\text { of } \\
\text { babies }\end{array}$ & $\begin{array}{l}\text { No (\%) } \\
\text { NNT } \\
\text { deaths }\end{array}$ & $\begin{array}{l}\text { Mortality/ } \\
1000 \\
\text { deliveries }\end{array}$ & $\begin{array}{l}\text { No (\%) } \\
\text { of } \\
\text { babies }\end{array}$ & $\begin{array}{l}\text { No (\%) } \\
\text { NNT } \\
\text { deaths }\end{array}$ & $\begin{array}{l}\text { Mortality/ } \\
1000 \\
\text { deliveries } \\
\end{array}$ & \\
\hline $\begin{array}{l}\text { Complete } \\
\text { Partial } \\
\text { None } \\
\text { Overall }\end{array}$ & $\begin{array}{c}153(19.7) \\
53(6.8) \\
569(73.4) \\
775(100)\end{array}$ & $\begin{aligned} & 4(16) \\
1 & (4) \\
20 & (80) \\
25 & (100)\end{aligned}$ & $\begin{array}{l}26.1 \\
18.9 \\
35.1 \\
32.3\end{array}$ & $\begin{array}{c}425(54.1) \\
47(6.0) \\
313(39.9) \\
785(100)\end{array}$ & $\begin{array}{r}7(58.3) \\
0 \\
5(41.7) \\
12(100)\end{array}$ & $\begin{array}{c}16.5 \\
0 \\
16.0 \\
15.3\end{array}$ & $\begin{array}{r}205(25.1) \\
82(10.0) \\
531(64.9) \\
818(100)\end{array}$ & $\begin{array}{c}2(18.2) \\
1(9.1) \\
8(72.7) \\
11(100)\end{array}$ & $\begin{array}{r}9.8 \\
12.2 \\
15.1 \\
13.4\end{array}$ & $\begin{array}{c}93(64.6) \\
11(7.6) \\
40(27.8) \\
144(100)\end{array}$ \\
\hline
\end{tabular}

184 other deliveries were recorded as follows:

184 other deliveries were recorded as follows: 19 in private homes; 163 in private 